\title{
Kako su mjerili stari Hvarani?
}

\author{
Željka Zorić, Jelena Jovanović
}

\section{Sažetak}

Je li moguće povezati matematiku, muzeje i arheologiju? Možemo li poučavati matematiku u muzeju? Bi li učenici bili zainteresirani za takvu vrstu podučavanja i učenja? Od idejnog rješenja preko realizacije interdisciplinarnog projekta Matematičari u muzeju, u radu se analiziraju višeslojni procesi i ciljevi muzejsko-edukativne radionice Kako su mjerili stari Hvarani?. Radionica se temelji na grčkoj metrologiji, a osmišljena je u skladu s kurikulumom nastavnog predmeta matematike za četvrti razred osnovne škole. Korelacijom i popularizacijom matematike i arheologije, $\mathrm{u}$ fokusu je drugačiji pristup provođenja nastave matematike, preciznije izvanučionička nastava u muzejskom okruženju, te evaluacija motivacije i reakcija učenika/sudionika muzejsko-edukativnih radionica.

Ključni pojmovi: interdisciplinarni projekt, muzejsko-edukativna radionica, nastava matematike, arheologija

Nakon obiteljskog izlaska na Noć muzeja pojavila mi se ideja kako bi bilo interesantno povezati poučavanje matematike i muzeje. Kroz predškolsko i osnovnoškolsko doba mojih sinova uočila sam da djeca rado sudjeluju u izvanškolskim edukativnim radionicama. Obilazeći različite muzeje diljem Europe susrela sam se s interaktivnim sadržajima i radionicama koje su s jedne strane plijenile pažnju i interes djece (i odraslih!), a s druge prenosile znanja i spoznaje. Kao nastavnik matematike često sam razmišljala kako bi bilo lijepo odvesti djecu u muzej i oplemeniti nastavu i nastavne sadržaje, te pokazati da se matematika može učiti i na drugačiji način.

Prirodno, prvo mi se postavilo pitanje što bi povezalo muzeje i matematiku? Jedan od odgovora je naravno povijest matematike. Kada sam se zaposlila na Prirodoslovno-matematičkom fakultetu u Splitu jedan od kolegija koji sam predavala bio je Povijest matematike. Tijekom pripremanja za nastavu, izučavanja različite literature i traženja materijala koji 
bi bili korisni u svakodnevnoj nastavi prvi se puta pojavila konkretna ideja o povezivanju muzeja i matematike. Kako obično biva u životu da se neke stvari same poslože, tada sam upoznala Jelenu Jovanović, kustosicu Arheološkog muzeja u Splitu, koja je imala sličnu ideju o muzejskoedukativnim radionicama. Vrlo brzo smo "kliknule", osmislile suradnju i započele interdisciplinarni projekt Arheološkog muzeja u Splitu (dalje Muzej) i Odjela za matematiku Prirodoslovno-matematičkog fakulteta u Splitu (dalje Fakultet) kojeg smo nazvale Matematičari u muzeju. Projekt Matematičari u muzeju realiziran je uz financijsku potporu Ministarstva kulture i Ministarstva znanosti i obrazovanja Republike Hrvatske. Riječ je o ciklusu od ukupno pet zasebnih, sadržajno jedinstvenih muzejsko-edukativnih radionica, osmišljenih u skladu s kurikulumom nastavnog predmeta Matematika, namijenjenih primarno učenicima od četvrtog do osmog razreda osnovne škole, a neke se radionice mogu prilagoditi i za srednjoškolski uzrast. Radionica za četvrti razred temelji se na grčkoj metrologiji, dok su ostale radionice tematski vezane uz pojedinog starogrčkog matematičara (Pitagora, Euklid, Tales, Arhimed) i njegov doprinos matematici. Radionicama smo dale kreativna imena kako bi dodatno zainteresirale učenike, to su:

Kako su mjerili stari Hvarani?, Istražimo Pitagorine figurativne brojeve, Geometrija u Muzejskom lapidariju, Koliko su visoki orlovi u Muzeju? i Tajne skrivene u amforama.
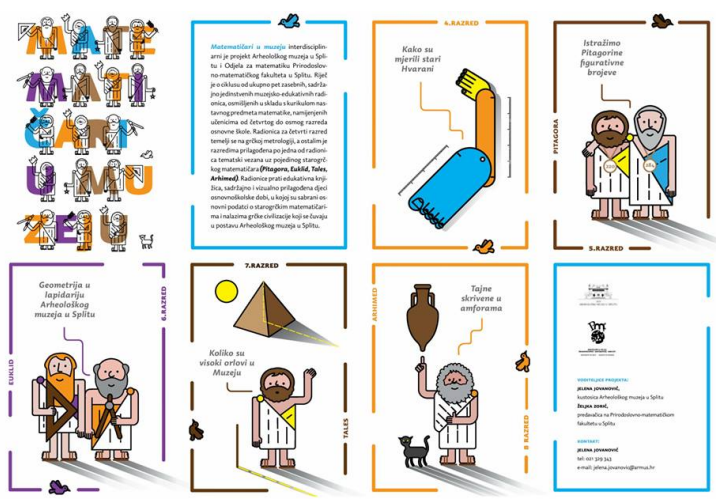

Slika 1: Letak projekta "Matematičari u muzeju"

Za potrebe projekta osmišljen je vizualni identitet koji smo osmislili u suradnji s dizajnerskim studiom. Radionice prati znanstveno-popularna knjižica, sadržajno i vizualno prilagođena djeci osnovnoškolske dobi, u kojoj su sabrani osnovni podatci o starogrčkim matematičarima i nalazima grčke civilizacije koji se čuvaju u postavu Muzeja. Za potrebe radionica osmišljeni su manipulativni didaktički materijali - Farska mjerka 
i modeli novca iz Krotona i Metaponta, kao i kaširani likovi starogrčkih matematičara koji krase prostore Muzeja i Fakulteta.

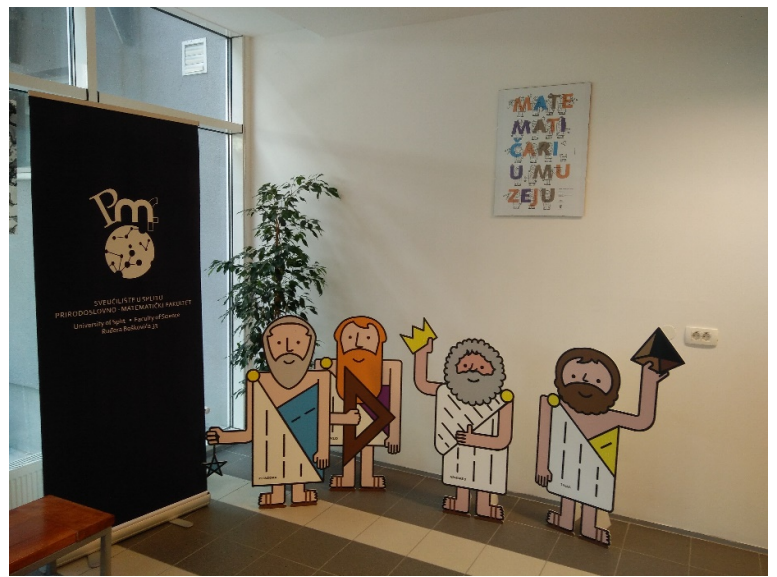

Slika 2: Grčki matematičari u Prirodoslovno-matematičkom fakultetu u Splitu

\section{Kako su mjerili stari Hvarani?}

Prva radionica $\mathrm{u}$ projektu Matematičari $\mathrm{u}$ muzeju učenike upoznaje $\mathrm{s}$ muzejom kao institucijom. Daje odgovor na pitanja: koja je uloga muzeja, što je arheologija, što se čuva u muzejima, te tko radi u muzeju? Učenici se upoznaju s povijesti Arheološkog muzeja u Splitu, koji je ujedno najstariji muzej u Splitu, u Hrvatskoj i u ovom dijelu Europe. Muzej je osnovan 1820. godine dekretom Dalmatinske vlade u Zadru. Sadašnju zgradu dao je izgraditi don Frane Bulić ugledni hrvatski arheolog i povjesničar.

Nakon povijesti samog Muzeja učenici obilaze lapidarij i stalni postav kako bi se upoznali sa spomenicima i prostorom čije će dimenzije kasnije mjeriti. Otkrivaju kako su sfinge završile u Splitu, legendu prema kojoj je don Frane Bulić zadržao sarkofag Dobroga pastira u Muzeju, te kako su vješti pomorci s grčkog otoka Para doplovili na našu obalu i ondje se nastanili. Parani su se nastanili na Hvaru, gdje su osnovali grad Far (Pharos) iz kojeg se razvio današnji Stari Grad. Zahvaljujući arheološkim nalazima koji se čuvaju u Muzeju znamo jako puno o životu starih Farana. Kraj Starog Grada nalazi se Starogradsko polje (farska hora) koje je bilo podijeljeno na jednake dijelove te je svaki Faranin imao svoju parcelu na kojoj je uzgajao sve što mu je potrebno za život. Granice među parcelama su kameni zidovi građeni u suhozidnoj tehnici koji su se uspjeli sačuvati sve do danas, cijelih 2400 godina, te su 


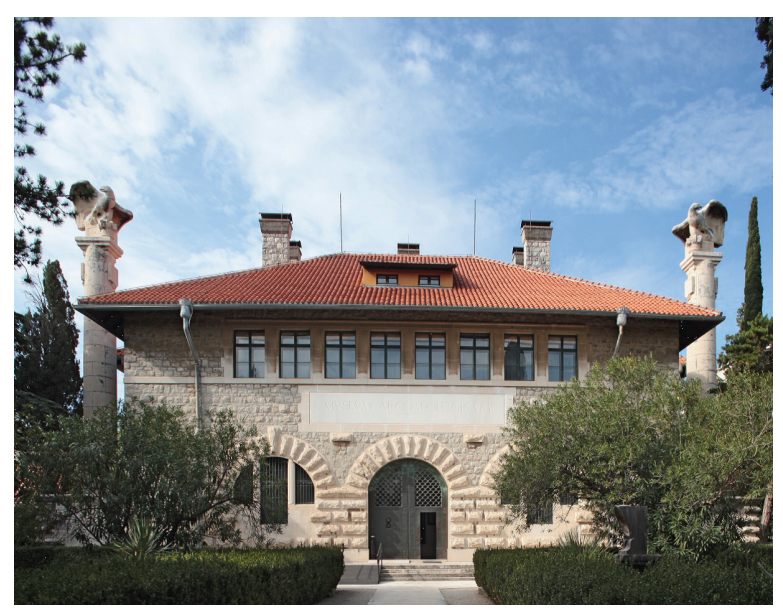

Slika 3: Arheološki muzej u Splitu

zbog svoje očuvanosti zaštićeni i uvršteni u UNESCO-ov popis svjetske baštine. Kako su mjerili stari Hvarani? Za razliku od današnjih mjera, Farani su duljine izražavali u mjernim jedinicama koje su nosile naziv po dijelovima čovjekova tijela, primjerice: prst, dlan, stopa i lakat.

Na slici 4 prikazana je Farska mjerka, a na njoj standardni odnosi koji vrijede za grčke mjerne jedinice te koliko bi Farske mjerne jedinice iznosile aproksimativno mjerene u centimetrima. Učenike nakon upoznavanja povijesti Muzeja i Farske mjerke očekuje matematički dio radionice. Nakon radionice učenici će znati mjeriti Farskom mjerkom dimenzije zadanog objekta i preračunavati Farske mjerne jedinice. Radionica je bazirana na suradničkom učenju, pa su učenici podijeljeni u skupine. Prije nego li im se podijele nastavni listići sa zadacima, otkrivaju kako se koristi Farska mjerka. Kroz pokušaje i promašaje, nepreciznosti i diskusiju zajednički pronalazimo najefikasniji način iskazivanja rezultata mjerenja odredenom Farskom mjernom jedinicom. Tada im se dijele mjerke i zadaci koje trebaju riješiti. Prvi zadatak je izmjeriti duljinu i širinu stolova u dvorani u kojoj se događa radionica. Cilj tog zadatka je osposobiti ih za rad s mjerkom. Rezultate mjerenja komentiramo i kroz diskusiju uspostavljamo odnose među Farskim mjernim jedinicama.

1 Farska stopa $=16$ Farskih prstiju $=4$ Farska dlana

1 Farski lakat $=24$ Farska prsta $=6$ Farskih dlanova 3 Farske stope $=2$ Farska lakta

Sada prelaze na mjerenje dimenzija nekog spomenika ili udaljenosti u Muzeju. Ovaj je dio učenicima izuzetno zanimljiv i zabavan is velikim ga 


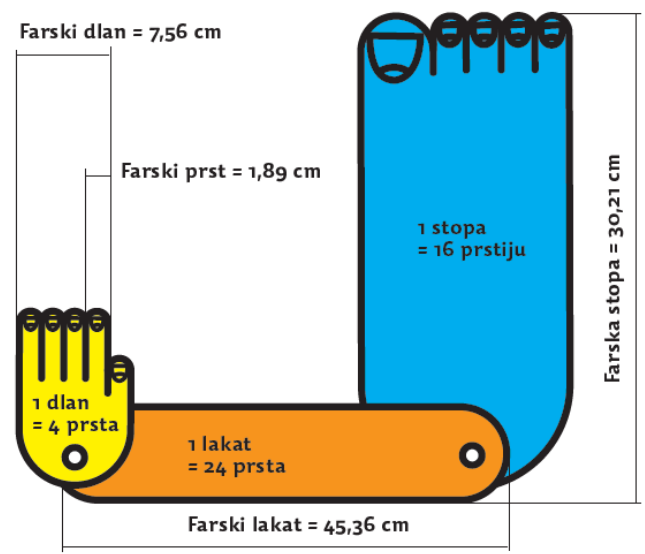

Slika 4: Farska mjerka

veseljem odrađuju. Mjerili su primjerice udaljenost od ulazne kapije do stepenica na ulazu u Muzej, duljinu velike izložbene dvorane, dimenzije postolja sfinge, i drugo. Po završetku mjerenja rješavaju zadnji zadatak u kojem izmjerene veličine moraju preračunati $u$ traženu mjernu jedinicu - najčešće iz stopa u lakte. Takvi zadaci učenicima su često teški i predstavljaju problem, pa je bilo interesantno uočiti koliko su brzo i s lakoćom preračunavali Farske mjerne jedinice. Na kraju provjerimo dobivene rezultate, ponovimo odnose među Farskim mjernim jedinicama i popričamo o onome što im se najviše svidjelo tijekom radionice.

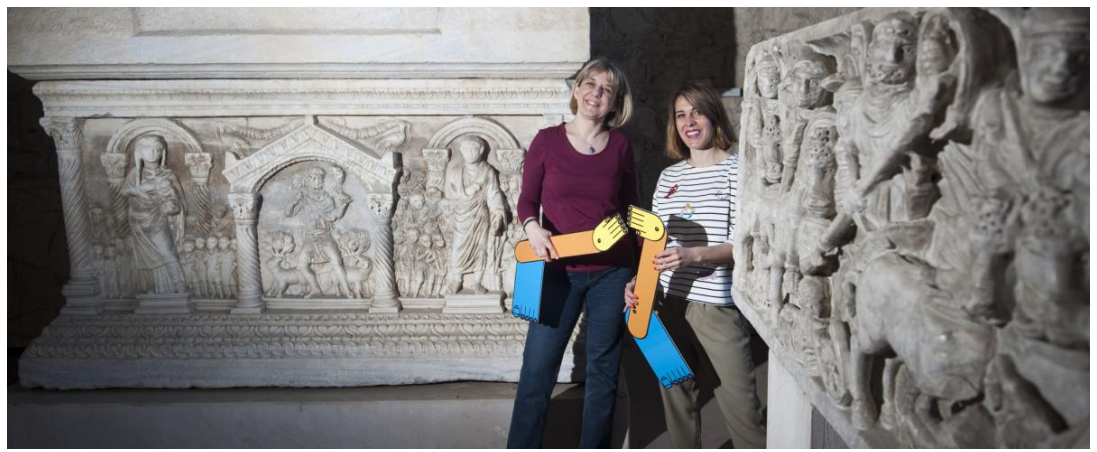

Slika 5: Voditeljice projekta Jelena Jovanović i Željka Zorić

Jedan od ciljeva projekta Matematičari u muzeju je popularizacija znanstvenog obrazovanja djece. Upoznavanjem nalaza iz svih faza grčke 
povijesti pronađenih na širem području srednje Dalmacije, djeca si mogu jednostavnije predočiti kada je i kako živio neki starogrčki matematičar. Na taj način uočavaju važnost arheologije kao znanosti i Arheološkog muzeja u Splitu kao najstarije muzejske institucije u Hrvatskoj koja čuva tako bogatu Grčko-helenističku zbirku. Ovako osmišljene radionice demistificiraju ovu muzejsku instituciju, ali i matematiku kao znanost, koja je nažalost često etiketirana kao najteži školski predmet. Starogrčki matematičari postaju ljudi od krvi i mesa, ljudi koji su koristili novac, čuvali vino $\mathrm{u}$ amforama, trgovali i eto bavili se matematikom. Uključivanjem studenata nastavničkih smjerova Odjela za matematiku Prirodoslovno-matematičkog fakulteta u Splitu omogućit će se stručno-metodičko usavršavanje i edukacija s ciljem popularizacije znanosti. Matematika i arheologija, na prvi pogled nespojive znanosti kroz kreativne radionice omogućavaju dekodirati specijalistički jezik znanosti u zabavne, lako pamtljive priče koje će djeca sa zanimanjem usvojiti. Primjenom znanstvenih metoda na matematičke zadatke i suvremenih principa nastave djeca će razbiti predrasude o matematici kroz igru i zabavu, te stvoriti vječne uspomene u muzeju.

\section{Literatura}

[1] F. M. Bruckler, Povijest matematike I, Sveučilište J.J. Strosmayera, Odjel za matematiku, Osijek, 2007.

[2] Burton, The History of Mathematics an introduction, 7th edition, McGraw Hill, 2011.

[3] A. Čavić, Stari Grad. Povijesni vodič, Stari Grad, 2004.

[4] J. Jovanović, Z. Zorić, Matematičari u muzeju, AMS i PMF, 2017.

[5] B. Kirigin, Starogradsko polje od prethistorije do ranog srednjeg vijeka (Stari Grad Plane from prehistory to early Middle ages), Mogućnosti 1-2, Split 1993.

\begin{tabular}{l} 
https://www.academia.edu/22981756/Starogradsko_polje_- \\
\hline od_prethistorije_do_ranog_srednjeg_vijeka_Stari_Grad_ \\
\hline Plane_from_prehistory_to_early_Middle_ages_Mogu\%C4\% \\
\hline 87nosti_1-2_Split_1993
\end{tabular}

[6] Z. Kurnik, Znanstveni okviri nastave matematike, Element, Zagreb, 2009.

[7] The Oxford Classical Dictionary, third edition, Oxford University Press 1996. 
[8] S. Popović, A. Čavić, Stari Grad Plain, vodič, Stari Grad 2013.

[9] Slobodna Dalmacija:

\begin{tabular}{|l|}
\hline WWW.slobodnadalmacija.hr/scena/kultura/clanak/id/ \\
\hline 478379/sjajan-splitski-projekt-evo-kako-aci-uce-matematikul \\
\hline -od-talesa-pitagore-arhimeda
\end{tabular}

[10] Encyclopedia Britannica:

www.britannica.com/science/measurement-system

Željka Zorić

Odjel za matematiku, Prirodoslovno-matematički fakultet u Splitu, Ruđera

Boškovića 33, Split

E-mail adresa: zzoric@pmfst.hr

Jelena Jovanović

Arheološki muzej u Splitu, Frankopanska 25, Split

E-mail adresa: jelena.jovanovic@armus.hr 